\title{
Men's ego-images represented on the fashion blogs in web 2.0 era
}

\author{
Sung Eun Suh ${ }^{\dagger}$ \\ Dept. of Clothing and Textiles, Sangmyung University, Korea \\ 웹 2.0 시대 패션에 나타난 남성의 자아이미지 \\ - 퍼스널 패션블로그를 중심으로 - \\ 서 성 은 $^{\dagger}$ \\ 상명대학교 의류학과
}

\begin{abstract}
In the era of 2.0 web, blog has become the media that men can express themselves with fashion more actively and independently, as paying much attention to their personal appearance and cultivating an upscale lifestyle. They often create their fashion images in the virtual space where enables a free and creative operations of self-expression. The study aims to identify the types of men's ego-images represented on the personal fashion blogs based on the framework of analysis from the previous research (Suh, 2014), to build the base data for analyzing men's fashion style in $21^{\text {st }}$ century that reflects changes in men's sexual images, and to verify the framework as comparing with the previous case study about the women blogs (Suh, 2014). The case studies conducted 5 men's personal blogs such as bryanboy, iamgala, little fashionisto, katelovesme, and stylentonic. The study results almost same types of women's ego-images as following. The imaginary ego-image is classified as narcissism, regression, identification, and virtuality, the social ego-image as symbolism of roles and others'desire, the real ego as primary instinct, practical reality, object a, jouissance and sexual perversion. The personal style of men shown on the fashion blogs appears as a significant factor to analyze male customers in the growing men's beauty and fashion market.
\end{abstract}

Keywords: web 2.0(웹 2.0), men's personal fashion blog(남성의 퍼스널 패션블로그), imaginary ego-image(상 상적 자아이미지), social ego-image(사회적 자아이미지), real ego-image(본질적 자아이미지)

\section{Introduction}

현대 패션에서 남성의 이미지는 다양한 매체를 통해 표현되고 있다. 웹 2.0 시대의 인터넷과 소셜 네트워크는 여성뿐 아니라, 남성이 패션을 통해 더
욱 적극적이고 주체적으로 자신의 이미지를 연출할 수 있는 기반이 되었다. 특히 블로그는 블로거가 이 미지 생산의 주체로서 자아를 표현하는 새로운 장 으로 활용되며, 많은 주목을 받고 있다. 21세기 남 성패션은 사회·문화·경제적 환경 요인의 변화에 따라 가치관과 신체적 이상미, 성 정체성의 변화, 건

Received 18 September 2014, revised 13 October 2014, accepted 13 October 2014.

$\dagger$ Corresponding author (sesuh@smu.ac.kr)

This is an Open Access article distributed under the terms of the Creative Commons Attribution Non-Commercial License (http://creativecommons.org/licenses/by-nc/3.0) which permits unrestricted non-commercial use, distribution, and reproduction in any medium, provided the original work is properly cited. 
강과 외모지향의 라이프 스타일, 감성과 개성의 추 구, 문화적 다원화, 그리고 한류의 열풍과 함께 아 이돌 스타를 비롯한 다양한 패션아이콘의 등장으로 인해 변화하는 다양한 남성의 이미지를 표현해왔다. 메트로섹슈얼(metrosexual), 위버섹슈얼(ubersexual), 크로스섹슈얼(crosssexual) 등 급격히 여성화, 혼성화 된 21세기 남성의 이미지를 대표하는 신조어도 등 장하였으며, 대중매체를 비롯한 소셜네트워크 기반 의 웹 2.0 환경에서는 자기표현의 자유롭고 창의적 조작이 가능한 가상공간을 바탕으로 다양한 남성의 이미지들이 더욱 극대화되어 나타나기도 한다.

본 연구는 자아표현의 장으로서 퍼스널 패션블 로그의 특성과 여성블로그를 중심으로 자아이미지 의 유형과 패션스타일에 대한 사례연구를 진행한 연구자의 선행연구(Suh, 2014)에서 도출한 분석틀 을 바탕으로 패션블로그에 나타난 남성의 자아이 미지를 분석하였다. 이는 선행연구에서 여성블로그 에만 한정하여 자아이미지를 분석하였기 때문에, 본 연구에서 남성블로그에 관한 분석을 통해 도출 한 종합적 결과를 바탕으로, 선행 연구의 분석 결 과를 검증, 비교하기 위함이다. 또한, 글로벌 패션 블로그에서 블로거의 퍼스널 스타일은 기존의 패 션 매체에서 제 3자의 시각으로 연출된 패션이미지 와 차별화되며, 이미지의 주체로서 블로거의 시각 이 반영된 자아이미지로서 의미를 지님을 확인하 고, 패션 시스템에서의 활용 가치를 시사하고자 함 이다. 그간 패션에 나타난 남성의 이미지, 남성성에 관한 국내 연구(Lee \& Byun, 2006; Lee \& Kim, 2009; Lee \& Jung; 2010, Yoon \& Yoo; 2011)는 주로 디자 이너의 컬렉션, 영화나 TV 드라마, 가수, 아이돌 등 스타 패션을 중심으로 분석되어 왔기 때문에 블로
그에 나타난 남성의 퍼스널 스타일은 21 세기 변화 하는 남성의 자아이미지와 패션의 연구에 의미있 는 단서가 되리라 사료된다.

연구의 방법은 첫째, 사용자 참여 중심의 환경으 로서 웹 2.0 시대의 특성과 최근 두드러진 외모지 향적 남성이미지 경향에 관해 고찰한다. 둘째, 사회 문화적, 정신분석학적 자아이미지를 바탕으로 도출 한 $\operatorname{Suh}(2014)$ 의 자아이미지 분석 틀을 적용하여 남 성의 대표적 퍼스널 패션블로그에 나타난 자아이미 지의 유형의 사례를 도출한다. 셋째, 도출된 남성의 자아이미지를 유형별 분석하고, 패션스타일 분석의 기초자료를 마련한다. 넷째, 여성블로그에서 자아 이미지 유형 분석 사례에 관한 선행연구 결과와 비 교·해석하여, 퍼스널 패션블로그에서 자아이미지 유형 분석의 틀을 검증한다. 사례연구는 블로그러 빈(bloglovin), 시그니처나인(signature 9) 등 블로그 랭킹사이트와 다양한 글로벌 패션 매체의 검증을 통해 남성의 패션블로그 중 상업적 패션 정보나 스 트리트 패션보다는 개인의 패션과 라이프스타일을 중심으로 자아이미지를 표현하고 있는 5 개의 퍼스 널 블로그를 〈Table 1〉과 같이 선정하였다.

연구의 범위는 매일 매일 업데이트되는 블로그 의 양이 방대하므로, 자아이미지 유형의 분석 틀에 따라 반복적으로 등장하는 주제들을 중심으로 대 표적 사례를 분석하였다. 각각의 블로그가 시작된 시점(2006년 이후)에서 2014년 8월까지 블로거 자 신의 이미지와 자신에 관한 글을 중심으로 총 250 개 (브라이언보이(bryanboy)에서 70, 아이엠갈라(iamgala) 에서 50, 리틀패셔니스토(littlefashionisto)에서 50, 케 이트러브미(katelovesme)에서 50, 스타일앤토닉(stylentonic)에서 30)의 포스트를 추출하였다.

$\langle$ Table 1〉 Men's personal fashion blogs for the case study

\begin{tabular}{c|c|c|c}
\hline Men's blogs & Period & Ego-images & Numbers of images \\
\hline www.bryanboy.com & $2006.3 \sim 2014.8$ & & 70 \\
\cline { 1 - 2 } www.iamgalla.com & $2007.2 \sim 2014.8$ & \multirow{2}{*}{$\begin{array}{c}\text { Bloggers' self images } \\
\text { and own articles }\end{array}$} \\
\cline { 1 - 2 } www.littlefashionisto.com & $2008.7 \sim 2014.8$ & & 50 \\
\cline { 1 - 2 } www.katelovesme.net & $2007.3 \sim 2014.8$ & & 50 \\
\hline www.stylentonic.com & $2012.5 \sim 2014.8$ & & 30 \\
\hline \multicolumn{2}{|c|}{ Total } & 250 \\
\hline
\end{tabular}




\section{Background}

\section{Blog in web 2.0 era}

웹 2.0은 데이터의 소유자나 독점자 없이 누구나 손쉽게 데이터를 생산하고, 인터넷에서 공유할 수 있도록 한 사용자 참여 중심의 인터넷 환경으로 블 로그(blog), 위키피디아(wikipedia), 딜리셔스(delicious) 등이 이에 속한다. 인터넷상에서 정보를 모아 보여 주기만 하는 웹 1.0 에 비해 웹 2.0 은 사용자가 직접 데이터를 다룰 수 있도록, 데이터를 제공하는 플랫 폼이 정보를 더 쉽게 공유하고, 서비스를 받을 수 있도록 만들어져 있다(Doopedia, 2014). 이는 웹 1.0 에서 사업자가 정보의 생산, 관리 및 보급을 주도 하던 것과는 달리, 2.0 에서는 이용자가 적극 참여함 으로써 정보와 지식을 창출하고 공유하는 패러다 임으로의 전환을 의미한다. 또한, 스마트폰과 같은 모바일 단말기기의 기술발전과 더불어 무선 데이 터 이용량이 폭발적으로 증가하면서 웹사이트 기 반이 아닌 모바일 환경의 인터넷 서비스들이 증가 하고 있으며, 개인이 인터넷의 중심이자 하나의 노드 (node)가 되는 SNS가 모바일 기술과 결합하여 강력 한 커뮤니케이션 도구가 되었다(Lee \& Jung, 2010). 이러한 매체 환경에서 개인은 언제 어디서나 자신 의 생각과 일상을 자신의 방식대로 손쉽게 업데이 트하고, 타인과 소통하는 것이 가능하다.

이제 소셜 네트워크는 개인 간의 관계를 지향하 는 의사소통의 도구일 뿐만 아니라, 기업이 소비자 를 대상으로 행하는 제 마케팅 활동의 채널과 방식 또한 변화시키고 있다. 정보의 이용자이면서 동시 에 생산자 역할을 수행하는 소비자가 프로슈머로 서 정보를 생성, 가공 및 전파시키는 주도적인 역 할을 수행함에 따라 기업의 대 소비자 전략 및 정 책도 변화하고 있다(Lee \& Jung, 2010). 블로그를 비롯한 웹 2.0 서비스에서 사업자들은 서비스를 이 용할 수 있는 환경만을 제공하며, 실질적인 내용을 채우고 즐기는 주체는 이용자들이 된다고 하였다. 서비스에 게시되는 글, 사진, 동영상 등의 개인 저 작물들은 이용자들의 자발적인 참여에 의해 만들 어지며, 개인은 실세계에서 표현하기 어려운 자기 표현의 욕구를 인터넷을 매개로 하여 자유롭게 표 출하고, 인터넷 사회에 공표 또는 출판하기도 한다.
이러한 개방과 공유, 그리고 이용자 참여라는 인터 넷 사회의 변화는 패션 산업에서도 패션 트렌드와 정보의 전달과 마케팅 방식에 변화를 가져온 중요 한 요인으로 부각되었다(Lee, 2006).

2010년 방송통신위원회가 조사한 블로그, 커뮤 니티, 미니홈피, 트위터 등 마이크로블로깅(microblogging) 등을 포함한 인터넷 이용실태에서 전체 이용자의 $65.7 \%$ 가 SNS를 사용하며, 이 중 남성이 $66.9 \%$, 여성이 $64.6 \%$ 로 나타났다. 종류별 이용 비 율로는 블로그가 $93.3 \%$ 로 가장 높게 나타났다(Lee \& Jung 재인용, 2010). 남성의 패션블로그는 최근 여성블로그 못지않게 다양해지고 있으며, 패션에서 여성에 비하여 상대적으로 수동적인 소비자였던 남성이 적극적으로 이미지 생산의 주체가 되는데 핵심적 역할을 하고 있다는 점에서 큰 의미를 지니 며, 이는 남성 패션산업에서 중요한 가치로 인정받 고 있다. 남성의 패션블로그는 개인의 자아표현욕 구를 실현할 뿐 아니라, 퍼스널 스타일이 21세기 패션에 나타난 남성이미지 형성과 변화에 미치는 영향을 확인할 수 있는 새로운 매체이다.

\section{Lookism in men's image and fashion blogs}

웹 2.0 시대 남성들은 문화 지향적이고 새로운 감성을 지니고 자신만의 패션 감각과 자아이미지 를 자유롭게 표현하고 있으며, 남성패션은 기존의 가치관과 영역을 초월하여 급속도로 변화하고 있 다. Lee, Byun and Lee(2006), Lee and Kim(2009), Yoon and Yoo(2011), Byun(2013) 등 남성의 현대 패션에 표현된 성이미지에 관한 최근 연구에서 메 트로섹슈얼, 위버섹슈얼, 크로스섹슈얼 등은 21세 기 남성의 라이프스타일을 대변하는 대표적인 키 워드로 나타났다. 특히 메트로섹슈얼은 패션과 트 렌드에 남다른 관심을 가진 현대 도시 남성을 일컫 는 말로서, 1994년 영국의 저널리스트 마크 심슨 (Mark Simpson)이 인디펜던트(Independent)에 기고 한 '거울쟁이 남자들이 온다(Here come the mirror men)'라는 칼럼에서 처음으로 사용되었다. 메트로 섹슈얼은 사회적으로 억압되어 있던 자기 안의 여 성성을 긍정적으로 부각시킨 남성으로 특히 오래 동안 여성들의 전유물로 여겨졌던 외모 꾸미기에 많은 시간과 돈을 투자하고, 유행을 선도하는 패션 
감각과 개성적인 스타일을 뽐낸다. 이들에게 장신 구나 메이크업, 피부 관리와 몸매 관리는 선택적 요 소가 아닌 필수적인 요소다(World culture dictionary, 2005). 남성의 외모 가꾸기에 대한 이러한 관심은 패션 산업에서 남성들을 가장 능동적인 소비층으 로 이끌어내며, 남성의 패션과 뷰티 산업을 더욱 가속화하고 있다. 남성의 패션블로그는 남성 블로 거의 주체적 자아이미지를 표출하는 공간일 뿐 아 니라, 현대 패션에 나타난 외모지향적 남성이미지 를 가장 잘 반영하고 있는 매체 중 하나이다. 남성 파워블로거들은 수많은 남성과 여성 팔로어들의 추종을 받으며, 디자이너와 마케터의 연구 대상으 로 주목받고 있다.

사례조사 대상으로 선정된 5 개의 남성블로그는 여성블로그와 마찬가지로 블로그의 초장기인 2006 2008년에 개설을 시작하여 개성있는 퍼스널 스타 일을 기반으로 성장하였다. 패션계의 주목을 받기 시작하며, 세계 3대 패션위크 VVIP 자리에 당당하 게 이름을 올린 것은 물론, 블로거브리티로 자리매 김하였다. 세계적인 디자이너와 콜라보레이션을 진 행하고, 수많은 팔로어에게 패션을 아우르는 라이 프 스타일에 영감을 주며, 남성의 패션이미지 형성 에 중요한 영향을 끼치고 있다. 브라이언보이는 필 리핀 마닐라 출신의 브라이언 얌바오(Bryan Grey Yambao), 아이엠갈라는 뉴욕과 캘리포니아를 베이 스로 활동하는 아담 갈라(Adam Gallagher), 리틀패 셔니스토는 캐나다 밴쿠버 출신의 쁘띠 사이즈 블 로거 맥 캐네스 리콘(Mc kenneth Licon), 케이트러 브미는 런던에서 활동하고 있는 스페인 출신 블로 거, 페라요 디아즈(Pelayo Diaz), 스타일앤토닉은 그 리스 아테네에서 패션매거진의 크리에이티브 디렉 터, 콘스탄티노스(Constantinos Tzacha)가 운영하고 있다. 이들의 스타일을 댄디, 섹시, 우아 등의 한 가 지 무드로 규정짓기는 어려운데, 평범하다고 불리 기에는 상식을 깨는 과감한 조화와 다양한 연출을 통해 세계 패션업계 종사자들에게 '발상의 전환'을 외치며 많은 귀감이 되고 있다. 특히 브라이언은 유명 디자이너들이 '여성용'이라고 내놓는 아이템 들도 과감하게 착용하며, 자신만의 스타일링을 연 출해내는데 때에 따라 스포티하게, 섹시하게, 여성 스럽게 자신만의 감각을 보여준다(“Design for Bryan
Boy", 2014).

\section{The framework of analyzing men's ego-image}

블로그에서 카메라, 컴퓨터 스크린, 블로거의 사 진 이미지, 그리고 블로거 자신의 상호 관계는 선행 연구에서 고찰한 정신분석학적 관점에서 응시(gaze) 를 중심으로 주체형성을 논한 Lacan의 시각이론을 적용하여 설명할 수 있다. 블로거는 카메라의 시선 을 이용하여 자신의 모습을 바라보고, 다시 블로그 를 통해 컴퓨터 스크린에 비춰진 자신의 이미지를 보는 주체가 되며, 블로그 이용자들의 댓글은 블로 거의 자아 이미지를 관찰하고 응시하는 역할을 한 다는 것이다. 여기에서 자신을 바라보는 타자의 시 선인 응시의 효과를 살펴볼 수 있다(Suh, 2014).

라캉의 응시는 '보는 것'에 주체의 개념이 들어 있는데, 본다는 것은 주체가 자율적인 존재라는 환 영을 깨고 주체가 통제하고 있다고 믿었던 시각장 에서 주체가 '보일 수 있다'라는 또 다른 시각장의 탄생을 의미한다. 우리의 시선을 지배하는 것을 응 시라 할 때, 우리는 시선의 주체일 뿐 아니라, 다른 시선의 객체이기도 하다. 따라서 이미지에는 항상 주체가 자신을 바라보는 방식이 실현되어 있는데, 이는 주체가 가시적 세계에서 대상들과 맺는 상상 적 관계 속에서 자신의 위치를 나타내는 방식이다 (Wright, 1989). 이러한 방식에 따라 세 가지 무의식 영역인 상상계, 상징계, 실재계와 연결시키는 이론 적 핵심을 형성하였는데, 상상계는 '보는 주체의 응 시', 상징계는 '보여지는 주체에 대한 응시', 실재계 는 '주체 내면의 응시'가 존재한다. 또한, 라캉은 무 의식 구조 안에 상상적이고 자아도취적인 이상적 자아(ideal ego), 사회적 이상을 상징하는 자아 이상 (ego ideal), 양심, 금지, 질책의 작인으로서 초자아 (super ego)라는 세 가지 자아개념을 제시하였다(Homer, 2006). 이러한 자아개념은 사회문화적 관점에서 정 체성, 자아이미지, 자기의식, 자아범주, 자기가치, 인상형성 등과 관련하여 연구되어왔다. 자아이미지 에 관한 분류는 $\operatorname{Sirgy(1982)ㅇㅢ~ㅅㅣㄹㅈㅔㅈㅏㅇㅏㅇㅣㅁㅣㅈㅣ(actual~}$ self-image), 이상자아이미지(ideal self-image), 사회 자아이미지(social self-image), 이상사회자아이미지 (ideal social self-image)가 대표적이다. 이상의 사회 문화적 자아개념과, 정신분석학에서 라캉의 무의식 


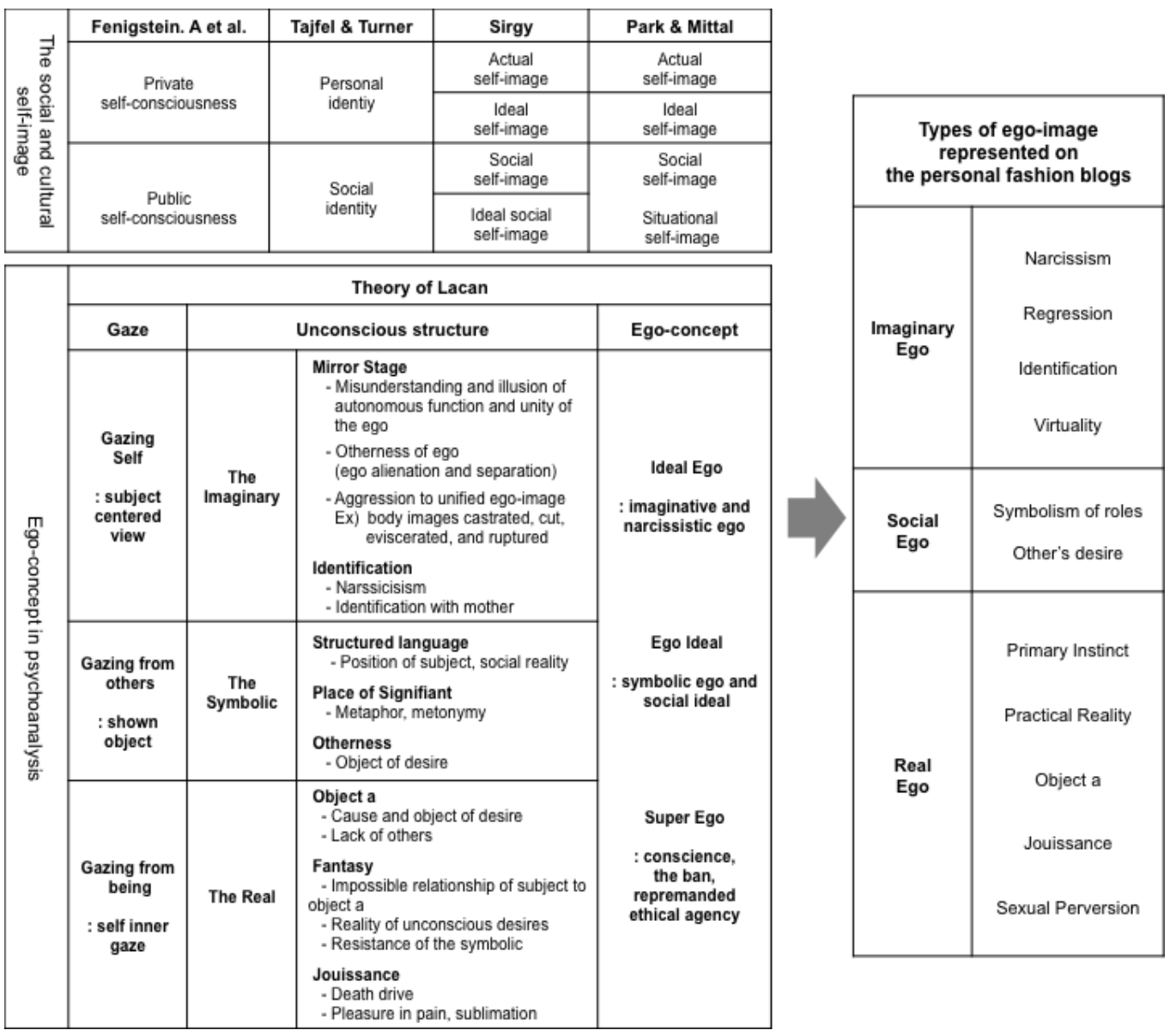

$\langle$ Fig. 1〉 The frame of analyzing the types of ego-image represented on the personal fashion blogs

구조를 반영한 자아개념을 바탕으로 연구자가 선행 연구에서 도출한 세 가지 자아이미지 유형은 상상적 자아(imaginary ego), 사회적 자아(social ego), 본질적 자아(real ego)로〈Fig. 1〉과 같다. 본 연구에서도 같 은 분석의 틀로 세부 속성에 따라 남성패션블로그에 나타난 자아이미지 유형의 사례를 분석하였다.

\section{The Case of Men's Ego Images on the Personal Fashion Blogs}

1. Imaginary ego image

1) Narcissism
선정된 5 개의 블로그에서 나르시시즘은 주로 블 로거의 취향과 패션스타일에 관한 소신으로 표현 되었다. $\operatorname{Suh}(2014)$ 의 여성블로그 사례에서는 바디 사이즈 등 신체적 조건에 대한 만족을 드러내는 경 우도 종종 보였으나, 남성들은 좀 더 패션을 통한 자기표현으로 자신감을 나타냈다. 브라이언보이의 〈Fig. 2〉에서 화이트 베드에 쿠션이 가득한 가운데 누드로 기대어 누운 채 지그시 눈을 감은 모습은 여성의 블로그 자주 등장하는 전형적인 나르시시 즘적 포즈이다. 브라이언은 자신을 마치 부활한 듯 한 모습으로 설명하며, 블로그뿐 아니라 인스타그 램(instagram), 트위터(twitter) 등 다양한 소셜네트 워크에서 만나볼 수 있음을 홍보했다. 2011년 11월 
28 일에는 비비드한 핑크 수트를 입은 모습을 포스 트하며, 프린트, 칼라, 가죽, 모피, 다양한 텍스쳐 등을 선호하는 자신의 취향을 설명하였다. 많은 사 람들은 화이트 버튼다운 셔츠에 카키 팬츠, 블랙 컨 버스 스니커즈와 같은 자연스러운 룩(effortless look) 을 선호하지만, 패션은 자신을 표현하기 위한 것이 기에 다른 사람의 시선을 의식하기 보다는 끊임없 이 옷과 놀이하는 자신에 관하여 이야기했다. 리틀 패셔니스토에서 리콘(Licon)은 XXS사이즈도 클 만 큼, 자신에게 맞는 사이즈의 옷을 찾기 어렵지만, 자르고, 붙이고, 바느질하고, 장식하는 등 자신만의 $\mathrm{DIY}$ 로 스타일 연출한다고 하였다. 또한 자신의 성 향에 대해 긍정적, 창의적, 행복한, 남을 의식하지 않는 자유로움을 추구하며, 삶에서 도전을 즐긴다 는 자신감을 표현하였다. 케이트러브미의 페라요는 2011년 6월 11일 자신을 패션에 대한 열정을 가지 고 모든 스타일을 시도하는 아담(Adam)이라고 소 개하였다. 금색 왕관을 쓰고 아담에게 힘을 주는 보랏빛 꽃을 배경으로 'live fast, die last(마음껏 살 다 죽자)'라는 메시지 티셔츠와 주얼 네크리스를 매치한 스타일을 포스트하였다(Fig. 3). 여기에서 왕관은 여성블로그와 마찬가지로 나르시시즘을 상 징하는 대표적인 아이템으로 사용되었다(Suh, 2014).

\section{2) Regression}

퇴행은 남성블로그에서도 여성블로그와 마찬가 지로 상상적 자아의 중요한 맥락으로 나타났다. 유 년기 시절의 모습과 어머니에 대한 동일시, 시대적 패션을 재현하는 것은 공통적인 주제이다. 다만, 여 성블로거는 유년기 추억에 대한 상황 설정이나 놀
이기구, 인형 등 소품 활용에 있어서 좀 더 적극적 이고, 구체적인 모습을 연출한 반면, 남성블로거는 비교적 단순하게 표현하는 경향으로 나타났다(Suh, 2014). 2009년 11월 1일 페라요는 1993년 할로윈 기념으로 유로디즈니(EuroDisney)에서 장난기 가득 한 아담스 페밀리(The Adams Family)의 형제, 퍼그 리(Pugsley)와 유사한 자신의 모습을 포스트하였다 (Fig. 4). 페라요는 2009년 12월 11에 비안웨스트우 드(Vivienne Westwood)의 블랙 스코트에 미키마우 스 헤어밴드를 한 자신의 모습을 포스트하였다. 피 터 팬처럼 모든 것을 꿈꾸고 긍정적이며, 원하는 대로 입으며, 항상 행복한 어린 아이로 지내고 싶 은 마음을 표현했다. 스타일앤토닉에서 콘스탄티노 스는 2014년 7월 22일 아테네 식물원에서 자신이 어린 시절 좋아했던 캐릭터 밤비(Bambi)가 그려진 티셔츠를 입고 있는 모습을 포스트하였다.

시대적 패션의 재현에 있어서는 여성블로거가 고 대의 신화적 이미지, 중세복식, 20세기 레트로 패션 까지 다양한 시대를 아울러 연출한 반면(Suh, 2014), 남성블로거는 주로 20 세기 패션의 재현에 한정되 어 나타났다. 2014년 4월 28일, 콘스탄티노스는 월 요일이라는 한 주의 시작에 활력을 불어넣고자, 올 드 스쿨 타투(old school tattoo)와 크리퍼(creepers) 로 50년대의 록커빌리(rockabilly) 감성을 연출하였 다(Fig. 5). 아이엠갈라에서 갈라는 2012년 7월 25 일, 70 년대 패션 요소 중 어깨패드나 하이 웨이스 트 벨바텀(bell-bottom)보다는 현대화에 좀 더 적합 한 스타일로 연출하기 위해 스키니 팬츠와 노트북 용 클러치를 선택하여 70년대의 앤드로지너스(androgynous) 분위기를 표현하였다.

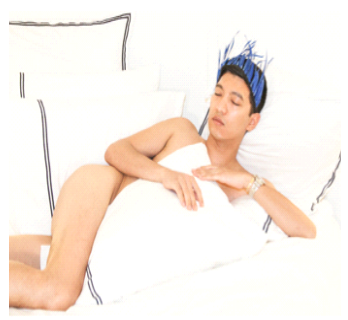

〈Fig. 2〉 Resurrection. From Bryan, G. Y.(2014a). www.bryanboy.com

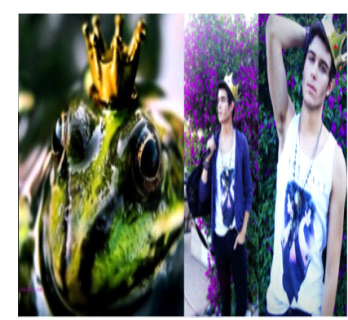

〈Fig. 3〉 Adam with crown. From. Adam, G.(2011c). www.iamgalla.com

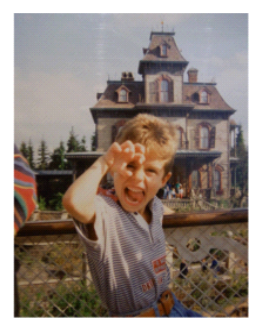

〈Fig. 4〉 Pugsley. From Pelayo, D.(2009b). www.katelovesme.net

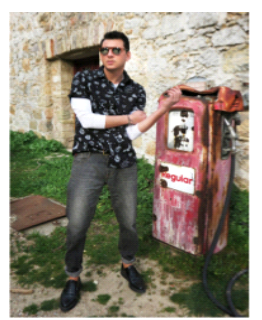

〈Fig. 5〉 50's Rockabilly. From Constantinos, T.(2014b). www.stylentonic.com 


\section{3) Identification}

남성블로그에서도 음악과 영화는 동일시의 소재 로 가장 빈번하게 등장하였다. 콘스탄티노스는 2014 년 3월 30일 케이티 페리(Kate Perry)의 '함성(Roar)' 의 가사에 영감을 받아서 포효하는 호랑이가 그려 진 프린트 티셔츠와 지세븐스타(G-Sevenstars)의 테 크노 선글라스를 매치한 스타일을 연출함으로써 밝고 에너지 넘치는 하루를 시작했다. 리콘은 2009 년 6월 27일 TV에서 우연히 마이클 잭슨을 기념하 는 다큐멘터리를 보고, 흰 양말과 블랙 슈즈, 페도 라, 아비에이터(aviator) 선글라스 등을 활용하여 잭 슨의 시그니처 룩을 재현하였다(Fig. 6). 2011년 11 월 1 일에는 피노키오의 이미지를 연출하였는데, 어 머니의 오래된 카프리 팬츠를 입고, 80 년대 코튼 벨트를 블루리본 타이로 변형, 아버지의 도구상자 에서 흰색 장갑을 활용했다. 리콘은 마치 동화 속 한 장면처럼 마법에 걸린 피노키오의 코가 거짓말 을 할 때마다 길어지는 듯한 모습이다(Fig. 7). 갈라 도 상상적 자아가 풍부하며, 음악과 영화, 소설 등 많은 문화 - 예술의 동일시를 보여준 대표적 남성 블로거이다. 2011년 1월 24일 〈Fig. 8〉과 같이 '해 리포터와 마법사의 돌(Harry Potter \& the sorcerers stone)'에 영감을 받아서 블랙 뿔테 안경과, 옐로우 $\&$ 래드 스트라이프 머플러, 크레스트(crest) 재킷을 입고, 책 표지의 포터와 같은 스타일을 연출하였다.

트렌드 동일시도 모든 블로그에서 공통적으로 나타나는 스타일 연출로 주로 패션 매거진과 룩 북, 특정 디자이너의 컬렉션, 시즌 색상과 프린트 등에 서 이루어진다. 갈라는 2011년 5월 3일, $\$ 50$ 에 구매 한 빈티지 아카데미 블레이저(academy blazer)를 그
레이 티셔츠와 함께 매치하였는데(Fig. 9). 이는 룩 북(lookbook.nu)에 소개된 여성의 더블 브레스트 블 레이저 스타일을 따라 한 것이고, 평소 빈티지 밀 리터리 재킷을 심플한 면 소재와 함께 입는 것을 좋아하기 때문이라고 하였다.

\section{4) Virtuality}

가상성은 카메라와 포토샵 등 디지털 효과를 사 용하여 이미지 표현을 가상적, 환상적으로 연출하 는 경우로 나타났다. 리콘은 2010년 5월 13일 '현실 에서 도피하기(escape from reality)'라는 제목으로 글을 남겼는데, 패션은 자신의 현실 도피구로 현실 을 싫어하기 때문이 아니라, 환상을 좋아하기 때문 이라고 하였다. 패션을 통해 어느 날은 선원으로 다음날은 밴드의 리더가 될 수 있으며, 사람들을 의식하지 않고 자신만의 세계를 누릴 수 있다는 것 이다. 콘스탄티노스는 2013년 2월 7일 플라토 아카 데미 레저 파크(Plato's Academy leisure park)에서 시각적 대화(visual dialogues)라는 멀티미디어 작품 을 배경으로〈Fig. 10〉과 같이 자신의 캐모플라지 (camouflage) 탑이 마치 작품과 하나가 된 듯한 착 시 효과를 연출하였다. 2014년 4월 9일 갈라는 마 이애미에서 트로피컬(tropical)의 태양에 흡수되는 듯한 모습을 연출하였는데, 태양의 검붉은 배경과 대조를 이루며 마치 하늘로 빨려 들어가는 듯한 모 습이다(Fig. 11). 또한, 파레요가 2009년 11월 21일 포스트한 이미지는 누드 톤의 바디 수트의 어깨위 로 사슴의 뿔이 자라는 듯한 가상적 신체를 연출하 고 있다(Fig. 12). 이는 상상적 자아의 중요한 모습 으로 현실에서 불가한 가상적 상황을 연출하여 이

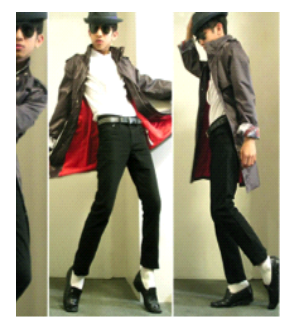

〈Fig. 6〉 Michael Jackson. From Mc, K. L.(2009). www.littlefashionisto.com

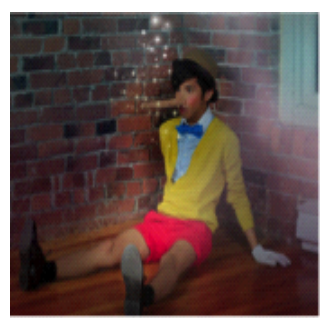

$\langle$ Fig. 7〉 Pinocchio. From Mc, K. L.(2011c). www.littlefashionisto.com

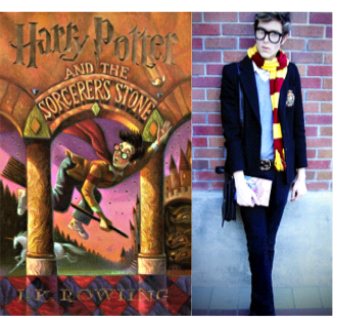

〈Fig. 8〉 Harry Potter style. From. Adam, G.(2011a). www.iamgalla.com

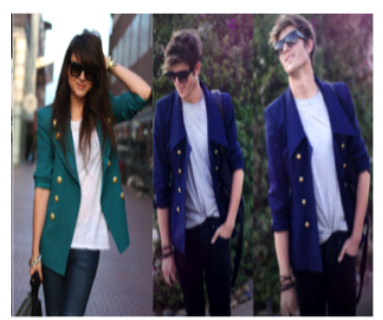

$\langle$ Fig. 9〉 Blazer trend. From. Adam, G.(2011b). www.iamgalla.com 


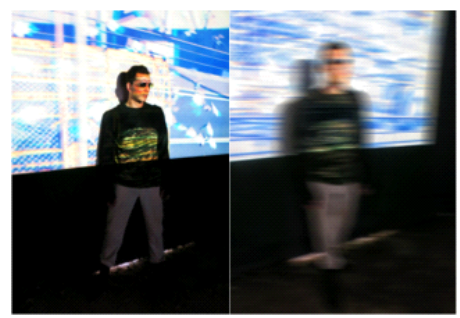

$\langle$ Fig. 10〉 Military effect. From

Constantinos, T.(2013).

www.stylentonic.com

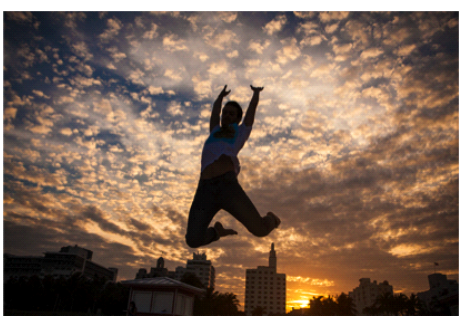

〈Fig. 11〉 Golden hour. From.

Adam, G. (2014). www.iamgalla.com

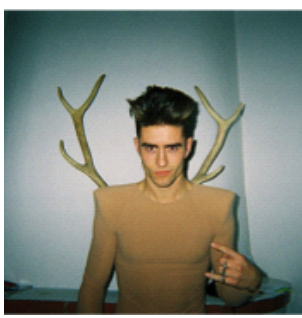

〈Fig. 12〉 Madrid gets horny.

From Pelayo, D.(2009c).

www.katelovesme.net

〈Table 2〉 Men's imaginary ego-image represented on the personal fashion blogs

\begin{tabular}{c|c|l}
\hline Imaginary ego & Detailed type & \multicolumn{1}{c}{ Content } \\
\hline Narcissism & Fashion style & - Pride and belief with own style \\
\hline \multirow{3}{*}{ Regression } & $\begin{array}{c}\text { Childhood } \\
\text { retro \& } \\
\text { vintage }\end{array}$ & $\begin{array}{l}\text { - Reminiscence of childhood and adolescence (family, birthday, fairy tale characters, toys, } \\
\text { amusement park, school life, etc.) } \\
\text { - Representing mother's style } \\
\text { - Representing 20c fashion as following items, silhouette, pattern, color, etc. }\end{array}$ \\
\hline \multirow{3}{*}{ Identification } & $\begin{array}{c}\text { Culture art } \\
\text { trend }\end{array}$ & $\begin{array}{l}\text { - Music (singer, lyris and melody), movie (story and characters), TV drama, animation } \\
\text { - Novel, fairy tale, art (photography, painting etc.) }\end{array}$ \\
& $\begin{array}{l}\text { Virtual } \\
\text { Virtuality }\end{array}$ & $\begin{array}{l}\text { - Representing a designer's concept or overall silhouette, details and a particular item } \\
\text { - Representing a similar style and pose from fashion magazine or celebrity fashion }\end{array}$ \\
\hline & \& body & $\begin{array}{l}\text { - Fairy-tale atmosphere (ex. Pinocchio), surreal space, dreamlike atmosphere } \\
\text { - Deviation and deformation of body } \\
\text { - Mirror effect: disassembled or cloned body }\end{array}$ \\
\hline
\end{tabular}

미지의 착시를 일으키고, 육체의 분리와 일탈, 변형 을 시도한다는 면에서 영화나 소설에서 나타나는 동일시와는 차별화된다. 이와 같이 남성블로그에 나 타난 상상적 자아이미지는 여성블로그에 비하여 상 대적으로 유형별 사례가 적고 다양하지는 않았으 나, 나르시시즘, 퇴행, 동일시, 가상성으로 세부속 성과 사례는 〈Table 2 〉와 같이 정리되었다. 이는 일 반적으로 남성이 여성에 비하여 감성과 상상력을 표현하는데 적극적으로 패션을 활용하지 않아왔기 때문이라 사료된다.

\section{Social ego image}

\section{1) Symbolism of roles}

사회적 자아이미지에서 역할의 상징성은 여성블 로그와 마찬가지로 블로거의 이름, 나이, 성별, 국
적, 거주지, 가족, 친구관계 등 공식적인 자기소개 와 더불어, 개인적 공간과 소지품, 패션스타일에 대 한 이미지와 글을 통해 블로그의 정체성을 알리는 경우이다(Suh, 2014). 콘스탄티노스는 블로그 메인 페이지에 그리스 아테네에 살며, 패션 메거진의 크 리에이티브 디렉터로 일하고, 패션과 음악, 탄산음 료를 좋아한다고 자신을 소개하며 'Athens(아테네)' 와 신전이 프린트된 블랙 티셔츠를 입고 마치 토닉 을 믹스한 탄산음료를 흔드는 듯한 모습을 포스트 하였다(Fig. 13). 이는 그리스라는 국적과 블로그의 타이틀과 같이 스타일에 토닉을 첨가하여 패션에 자신만의 활력과 에너지를 부여하고자 하는 블로 거의 정체성을 표현한다. 블로거의 침실과 옷장, 집 안 등 사적 공간의 경우, 남성블로그에서는 여성블 로그의 사례(Suh, 2014)에 비하여 덜 등장하였다. 하지만 블로거의 방은 블로거의 진정한 스타일과 
정체성을 드러내는 중요한 공간이자 배경이다. 2010 년 9월 26일, 페라요는 인디펜던트(The independent newspaper)에 실린 자신의 방의 이미지를 포스트하 였다(Fig. 14). 대외활동이 많아질수록 다양한 도시 로의 여행이 잦아지면서 집에 머무르는 시간이 줄 어들지만, 여행에서 돌아올 때면 자신의 방은 늘 편안한 휴식과 충전을 제공해 주는 안식처로 등장 한다.

블로거의 역할과 블로그에 대한 비전은 남성블 로그에서도 반드시 등장하는 사회적 자아이미지다. 갈라는 2013년 5월 9일 포스트에서 그동안 블로그 를 진행하면서 다양한 영감을 가지고 작업해 왔으 며, 앞으로도 아트디렉터(art director)로서 자신만의 깊이 있는 에디토리얼(editorial)을 한 달에 2개 정 도 출간하고 싶다는 포부를 밝혔다. 블로거의 인간 관계는 가족을 비롯하여 일상을 함께하는 친구와 동료를 중심으로 나타났다. 여성블로그에서는 남자 친구가 많은 비중을 차지하고, 사진을 찍어 주는 등 실질적 운영뿐 아니라, 정신적 후원자로서 역할 을 하는 경우가 많으나(Suh, 2014), 남성블로그에서 는 연인에 대한 내용이 거의 등장하지 않고, 취향 과 성향이 잘 맞는 여자 친구가 동료로 등장하는 것이 특징적이다. 콘스탄티노스는 2012년 10월 29 일 베스트 프렌드 칼리(Kalli)와 디미트라(Dimitra) 와 함께 주말 오후를 보낸 우정이 가득한 사진을 포스트하였다(Fig. 15). 또한 패션위크에서 동료 블 로그들과 함께 파티에 참여하거나, 스케줄이 없는 시간을 함께 보내는 모습을 보여주는 경우도 많다.

남성블로거의 사회활동에 관하여는 여성블로그 분석결과(Suh, 2014)와 마찬가지로 자주 등장하지
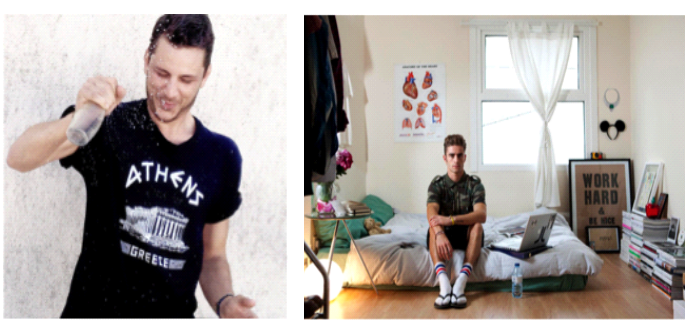

$\langle$ Fig. 13〉 Athens. From 〈Fig. 14〉 My room in London. Constantinos, T.(2012a). From Pelayo, D.(2010). www.stylentonic.com www.katelovesme.net

는 않지만, 한 두 사례에서 블로거의 의식을 엿 볼 수 있다. 2011년 8월 31일 브라이언은 남아프리카 공화국의 소웨토(Soweto)에 방문하여, 1976년 6월 발생한 인종차별반대 시위인 반아파르트헤이트(AntiApartheid) 폭동 당시 희생된 13세 소년, 헥터 피터 슨의 기념관(the Hector Peterson memorial)에 기부 를 하였고, 그 지역의 아이들과 사진을 찍은 모습 을 포스트하였다(Fig. 16). 페라요는 2012년 12월 17 일 자신의 블로그가 삶을 즐기고 패션을 축하하 는 유머있는 공간이고, 평소 전쟁이나 정치에 관한 생각은 다루지 않지만, 때로는 패션이 아무 말이 필요 없이 메시지를 전달하는 가장 적합한 매체가 되기도 한다면서 평화(peace)라고 크게 쓰인 아크 네(Acne) 풀오버를 포스트하였다.

\section{2) Other's desire}

타자의 욕망은 사회적 자아이미지의 가장 주된 속성으로 블로거의 주체적 이미지 연출에 대한 타 인의 시선이 강조된 현상이다. 블로거의 탁월한 패 션 감각과 글로벌한 라이프 스타일, 화려하고 매력 적인 패션계와의 인맥과 콜라보레이션은 팔로어들 에게 최신 트렌드를 비롯하여 많은 볼거리와 패션 에 대한 대리만족을 제공한다. 이는 남성블로그에 서도 여성블로그와 마찬가지로 유사한 사례로 분 류되었다. 대표적인 스타일 소개 및 제안은 새롭게 구매한 또는 기존의 아이템을 활용하여, 자연스러 운 믹스 앤 매치나 DIY를 통해 블로거만의 개성있 는 스타일을 연출하는 것이다(Suh, 2014). 2013년 7 월 11일 콘스탄티노스는 '나의 트로피컬 블랜드(my tropical blend)'라는 주제로 트로피칼 프린트 셔츠,

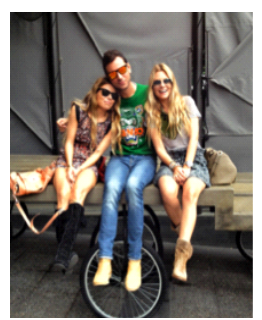

〈Fig. 15〉 Best friends. From Constantinos, T. (2012b). www.stylentonic.com

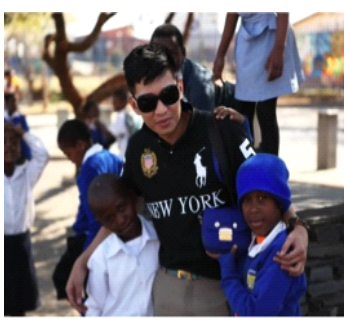

〈Fig. 16〉 Volunteer at Soweto. From Bryan, G. Y. (2011c). www.bryanboy.com 
그린 카키 팬츠, 그라시안 샌들(Grecian sandals), 그 리고 핸드메이드 주얼리를 착용하여 그리스의 싱 그러운 여름을 표현하였다(Fig. 17). 여행지 블로 거의 스타일도 팔로어들에게 신선한 영감을 준다. 2014년 4월 20일 브라이언은 베니스에서 첫 눈에 반해 구매한 샤넬 백을 두바이 사막 보존지역(Dubai Desert Conservation Reserve)에서 전통복식과 함께 연출하였다. 쇼핑할 때 맘에 드는 물건을 발견하면 자신도 모르게 이성적 판단보다는 충동구매를 하 게 되는 심리 설명하였는데, 이는 모든 패션소비자 가 경험하게 되는 것으로 팔로어로 하여금 또 다른 욕망을 불러일으킨다. 2011년 3월 2일에는 뉴욕과 밀라노에 이어 파리 패션위크에 방문하여 티에리
머글러(Thierry Mugler) 쇼에 초대받아 여성스럽고 부피감 있는 화이트 퍼 베스트(white fur vest)에 프 린트 팬츠를 입고, 가로등에 기대어 담배 한 개비 를 들고 있는 모습을 보여준다(Fig. 18). 레이디 가 가(Lady Gaga)가 올지 모른다는 브라이언의 설렘 처럼, 크로스섹슈얼을 연상시키는 이미지다.

성취는 블로거의 다양한 콜라보레이션이 주를 이루는데, 갈라와 브라이언은 연구 대상의 남성블 로거들 중 가장 많은 하이앤드 디자이너와 콜라보 레이션을 진행하였다. 2013년 9월 12일, 갈라는 제 냐(Zegna), 디테일 매거진(Details magazine)과 협업 하여 화보촬영을 하였고, 개인적으로 가장 맘에 드 는 버건디(burgundy) 터틀넥 스웨터에 더블브레스
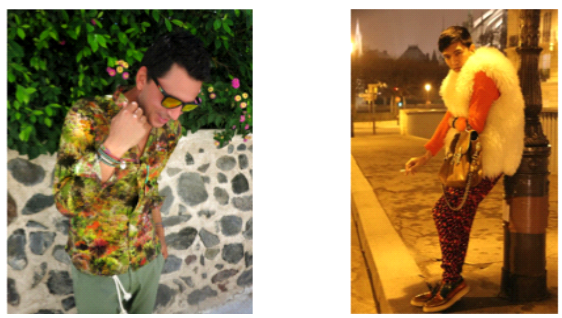

$\langle$ Fig. 17〉 Tropical blend 〈Fig. 18〉 Mugler invitation From Constantinos, T.(2013). From Bryan, G. Y.(2011a). www.stylentonic.com www.bryanboy.com

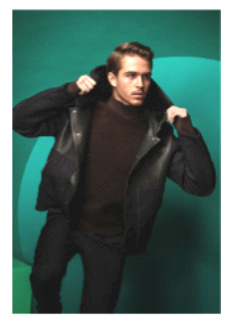

〈Fig. 19〉 Zegna Collao. From. Adam, G.(2013b). www.iamgalla.com

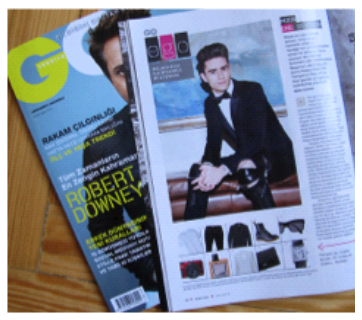

〈Fig. 20〉 Interview with GQ men. From Pelayo, D.(2014). www.katelovesme.net

$\langle$ Table 3〉 Men's social ego image represented on the personal fashion blogs

\begin{tabular}{c|c|l}
\hline Social ego & Detailed type & \multicolumn{1}{c}{ Contents } \\
\hline \multirow{4}{*}{$\begin{array}{c}\text { Symbolism } \\
\text { of roles }\end{array}$} & $\begin{array}{c}\text { Self introduction } \\
\text { roles \& vision } \\
\text { of blogger }\end{array}$ & $\begin{array}{l}\text { - Age, gender, nationality, name, occupation, etc. } \\
\text { - Purpose, roles and vision of the bog, massage to followers (ex. greetings of anniversary) }\end{array}$ \\
\cline { 2 - 4 } & Human relation & $\begin{array}{l}\text { - Family photos (family event and travel, with siblings, etc.) } \\
\text { - Friends and colleagues(birthday part, travel, concert, various events and parties related } \\
\text { fashion) }\end{array}$ \\
\cline { 2 - 4 } & Social activity & - Volunteer activity in Soweto, anti-war, wish for peace \\
\hline \multirow{5}{*}{\begin{tabular}{c} 
Other'desire \\
\cline { 1 - 3 }
\end{tabular}} & $\begin{array}{c}\text { Personal style } \\
\text { suggestion }\end{array}$ & $\begin{array}{l}\text { - Individual style introducing new purchased items or styling through DIY, mix \& match, } \\
\text { sponsored wardrobe, etc. }\end{array}$ \\
\cline { 2 - 4 } & - Introducing personal taste with exotic or ethnic images from various travels \\
\cline { 2 - 4 } & $\begin{array}{l}\text { - Blogger's daily fashionable styles during fashion week in the global cities } \\
\text { - Introducing designer's collection \& the atmosphere in the show and the backstage }\end{array}$ \\
\hline
\end{tabular}


트 코트를 입은 이미지를 포스트하였다(Fig. 19). 2014년 6월 13일 페라요는 지큐 맨 어워드(GQ men Awards)를 위해 터키 이스탄불에 방문하였고, 지큐 매거진에 자신의 블로그와 앞으로 진행할 콜라보 레이션, 그리고 자신의 필수적인 부분에 관해 인터 뷰하였다(Fig. 20). 또한, 2012년 11월 23일에는 프 랑스 대사의 집에서 열린 프릭스 드 라 보드 마르 끌레르(Prix de la moda Marie Claire)에 참석하여 자신이 가장 좋아하는 스페인 출신의 디자이너, 데 이비드 델핀(David Delfin)이 디자이너 어워드를 받 고, 배우, 모델, 패션잡지 관계자들 등 많은 셀러브 리티와 함께 한 사진을 포스트하였다. 2013년 3월 30 일 브라이언은 프로젝트 런웨이 코리아 올스타 (Project Runway Korea All-Stars)의 심사위원으로 한국을 방문한 내용을 포스트하였는데, 콘테스트가 바로 브라이언의 스타일을 만들어내는데 도전하는 것임에 대해 자랑스러워했다. 이는 블로거가 세계 적인 패션아이콘으로서 자신의 퍼스널 스타일을 인정받은 것이라는 점에서 의미가 크다. 이와 같이 남성블로그에 나타난 사회적 자아이미지는 여성블 로그에서 나타난 유형의 결과와 마찬가지로 역할 의 상징성과 타자의 욕망으로 분류되었고, 세부속 성과 사례는 〈Table 3〉과 같다.

\section{Real ego-image}

\section{1) Primary instinct}

본질적 자아이미지에서 1 차적 본능은 블로거의 식욕, 건강, 심리상태 등으로 나타났다. 브라이언은 2007년 10월 5일 포테이토 크레이빙(Potato Craving) 이라는 제목으로 새벽 4시에 감자껍질을 벗기고, 요 리를 시작하는 자신의 모습을 포스트하였다. 리콘 은 2009년 7월 30일 식앤핫(Sick and Hot)이라는 제 목으로 무더운 날씨 가운데 불편하고 컨디션과 고 통스럽고 짜증스러운 다양한 감정들을 맥 $(\mathrm{Mac})$ 어 플리케이션 중 포토 부스(photo booth)를 활용하여 연속 촬영한 이미지를 포스트하였다. 이와 유사하 게〈Fig. 21〉은 2010년 2월 25일에는 열과 목감기에 시달리고 있는 자신의 모습을 표현한 이미지다. 날 씨와 계절, 시간의 흐름도 블로거가 종종 영감을 받 는 요소인데, 2014년 6월 19일 콘스탄티노스는 바닷
가 석양의 아름다운 하늘과 생동감 있는 여름의 오 후를 비비드한 래드, 블루, 옐로우, 그린이 칼라 블 럭된 가벼운 나이키 테크-윈드러너(tech-windrunner) 재킷으로 표현하였는데, 바다 바람에 날리는 재킷 의 모습이 하나가 되어 아름다운 조화를 이루고 있 다(Fig. 22). 2014년 8월 17일에는'네츄럴리 스위트 (Naturally Sweet)'라는 제목으로 에메랄드빛 바다 를 배경으로 올 오버 스마일(all over smile) 패턴의 화이트 머슬 탱크(muscle tank)에 수박껍질 색상과 같은 그린 썬캡(sun cap)을 쓰고 있다(Fig. 23). 인생 은 한 조각 수박처럼 달콤하다는 콘스탄티노스의 표현과 같이 아름다운 바다, 스마일, 새빨간 수박의 위트 있는 조화는 삶에 대한 긍정적 심리상태를 표 현한다.

\section{2) Practical reality}

실제적 현실은 블로거가 포스트한 이미지 이면 에 드러나지 않는 현실적 상황을 묘사한 부분이다. 여성블로그와 마찬가지로 본질적 자아의 많은 부 분을 차지하지는 않지만, 때때로 이미지에서 풍겨 지는 모습에 비하여 실제 상황이 전혀 다른 스토리 를 가지고 있거나, 블로거의 또 다른 심리상태를 설명하는 경우로 나타났다(Suh, 2014). 2005년 3월 22 일 브라이언은 부활의 성주간(Holy Week) 동안 필리핀 보라카이에서 루이비통 매장의 윈도우를 배 경으로 쇼핑하고 있는 사진을 포스트하였다. 브라 이언의 모습은 여행에 필요한 비치 타올을 구매하 여 즐거워 보이기만 하지만, 실제 보라카이의 날씨 는 더위가 극에 달해서 가만히 있어도 땀이 흘러 무척 불편한 상황이라고 설명하였다. 또한, 집에 돌 아와서는 밤이 늦은 시간까지 앞으로 6 일간 다녀올 여행에 필요한 짐을 싸느라 고민하고 있다고 덧붙 였다. 이렇듯 블로거가 종종 포스트한 이미지 이면 에 자신이 처한 실제적 현실을 묘사하는 경우, 본 질적 자아를 드러내고 있는 것이다.

\section{3) Object a}

대상 $\mathrm{a}$ 는 라캉의 정신분석학에서 욕망의 대상과 원인을 가리킨다. 이는 여성블로그에서 주로 패션 의 속성을 드러내는 물신적 페티시즘으로 표현되 곤 하였다(Suh, 2014). 브라이언은 2012년 8월 10일 


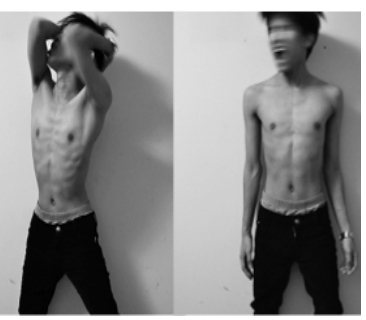

$\langle$ Fig. 21〉 Sick. From

Mc, K. L. (2010a).

www.littlefashionisto.com

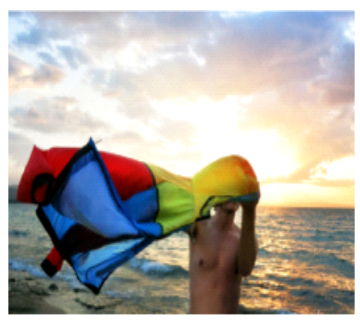

〈Fig. 22〉 Vigorous sunset.

From Constantinos, T.(2014c). www.stylentonic.com

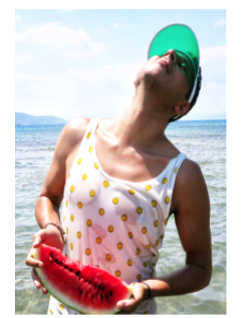

〈Fig. 23〉 Naturally sweet.

From Constantinos, T.(2014e). www.stylentonic.com

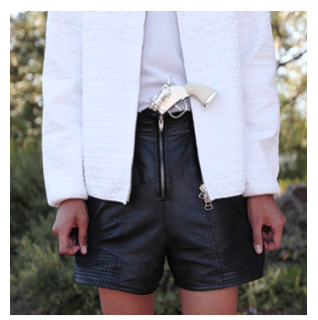

〈Fig. 24〉 Worn to death. From Bryan, G. Y.(2012). www.bryanboy.com
‘죽도록 입고 싶은(worn to death)'라는 포스트에서 자신이 섬세한 재질과 홀(hole, perforations)에 집착 하여, 3.1 필립 림(Phillip Lim)의 화이트 텍스쳐드 (textured) 재킷과 유니클로의 매쉬(mesh) 탑, 그리 고 알렉산더 왕(Alexander Wang)의 가죽과 스웨이 드(suede)의 천공 쇼츠(perforated shorts)를 입고 있 음을 설명하였다(Fig. 24). 특히 고가의 알렉산더 왕 쇼츠에 관하여는, 일생에 몇 번쯤 버는 돈을 모 두 투자해서라도 사고 싶은 것이 있는데, 바로 이 것이라고 표현했다. 블로거의 재치 있는 연출이기 도 하지만, 이미지가 가슴에서 허벅지 부분까지만 클로우즈업(close-up)되어 있고, 블랙 앤 화이트의 심플한 색상 대비와 함께 섬세한 텍스쳐와 매쉬, 펀칭이 조화를 이루는 가운데 쇼츠의 앞지퍼 위로 실버 메탈의 권총이 꽂혀 있다. 이는 블로거의 페 티시즘을 매우 상징적으로 표현하고 있는 것이다. 이러한 물신적 욕망 외에도 도피하고 싶은 파라다 이스, 미지의 세계에 대한 열망 등도 대상 $\mathrm{a}$ 를 표현 하는 요소로 나타났다.

\section{4) Jouissance}

본질적 자아의 주이상스는 체제의 반항, 욕망의 좌절과 고통, 승화된 쾌락을 의미한다. 주로 블로거 의 내적 갈등과 극복의 형태로 표현되는데, 브라이 언은 2011년 6월 10일 자신의 머리에 마르지엘라 (Margiela)의 커다란 여우 털 해드피스(headpiece)를 쓰고 있는 이미지를 포스트하며, 자신의 머리카락 처럼 자유롭게 살다가 죽고 싶다고 하였다(Fig. 25). 이는 실제 삶에서 다양한 현실 제약을 직시하지만, 자 유로운 삶에 대한 내적 소망을 머리장식을 통해 표현
하고 있다는 점에서 주이상스의 승화적 속성이다. 리 콘은 2011년 3월 7일 '어두운 생일(dark birthday)'이 라는 제목으로 그레이 톤의 이미지를 포스트하였 다. 약간은 비장한 표정을 하고, 쉬폰 소재의 탑을 몸에 감듯이 둘러서 추상적인 형태를 만들어 옷의 구조나 디테일을 파악하기는 힘들지만, 단순히 즐 겁고 행복한 생일이기 보다는 삶에 대한 고뇌를 표 현하는 듯한 느낌을 주고 있다(Fig. 26).

\section{5) Sexual perversion}

성적 도착은 성에 대한 강조와 왜곡을 의미하며, 여성블로그에서는 주로 가슴, 엉덩이 등 성적 부위 를 노출, 강조하거나, 속옷의 겉옷화, 코르셋 등으 로 성적 억압을 표현하였다(Suh, 2014). 남성블로그 에서도 유사한 방식으로 나타났으며, 차이점은 여 성 착의로 성적표현을 강조하는 경우였다. 브라이 언은 2005년 3월 21일, 레이스 달린 여성의 슬립 드 레스에 블루 스타킹을 신고 있는 모습을 포스트하 며, 18 세 생일을 맞이하여 친구들과 재미로 어린 시절 자주 했던 여장 놀이를 하게 되었다고 설명했 다. 이미지에서 브라이언은 여성의 골드 체인 백까 지 어깨에 메고 마치 모델처럼 당당한 포즈를 취하 고 있는데, 평소 여성 아이템을 즐겨하는 그의 패 션 취향을 예측할 수 있는 부분이다. 2009년 1월 28 일 페라요는 찢어진 블랙 망사 스타킹에 하이힐을 신은 자신의 둔부와 다리를 클로우즈업 한 이미지 를 포스트하였다(Fig. 27). 또한, 리콘은 2010년 1월 15일 상반신 누드에 오래된 여성의 벨트를 감고, 손목에 두꺼운 스터드(stud) 팔지를 하고 있는 자신 의 모습을 포스트하였다(Fig. 28). 이것은 여성블로 


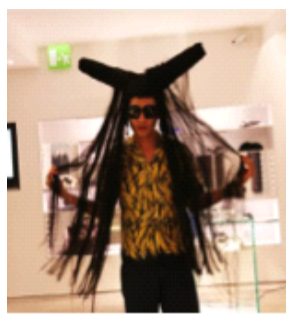

〈Fig. 25〉 Living as free as

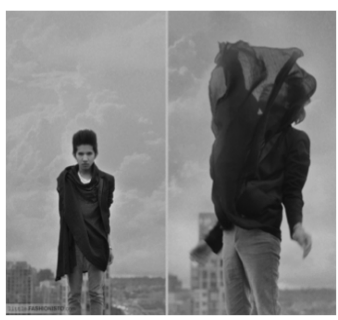

〈Fig. 26〉 Dark birthday. my hair. From Bryan, G. Y. From Mc, K. L.(2011a). (2011b). www.bryanboy.com www.littlefashionisto.com

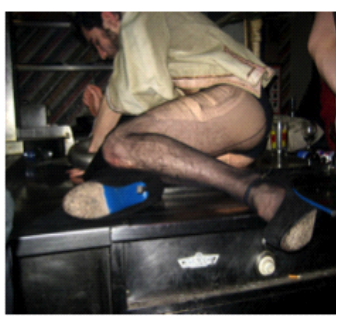

〈Fig. 27〉 Louboutin

high-heel. From Pelayo,

(2009a). www.katelovesme.net www.littlefashionisto.com

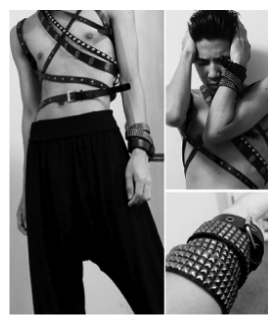

〈Fig. 28〉 Tangled.

$\langle$ Table 4〉 Men's real ego image represented on the personal fashion blogs

\begin{tabular}{c|l|l}
\hline Real ego & \multicolumn{1}{|c}{ Detailed type } & \multicolumn{1}{c}{ Contents } \\
\hline $\begin{array}{c}\text { Primary } \\
\text { instinct }\end{array}$ & Physiological and psychological instinct & $\begin{array}{l}\text { - Heath condition (tired, sick, pain), appetite, } \\
\text { - Psychological condition (gloomy, joy, peaceful, passionate) } \\
\text { - Weather, season, flow of time }\end{array}$ \\
\hline $\begin{array}{c}\text { Practical } \\
\text { reality }\end{array}$ & Unexposed situation in the image & $\begin{array}{l}\text { - Describing actual, practical situation beyond the image that } \\
\text { blogger posted }\end{array}$ \\
\hline Object a & Cause and object of desire & - Fetishism for materialistic fashion, escaping to paradise \\
\hline $\begin{array}{c}\text { Jouissance } \\
\text { Sexual } \\
\text { perversion }\end{array}$ & $\begin{array}{l}\text { Resistance of social customs, frustration } \\
\text { and pain of desire, sublimation }\end{array}$ & $\begin{array}{l}\text { - Fear of unstable life } \\
\text { concept }\end{array}$ \\
\hline
\end{tabular}

그에서 코르셋의 이미지와 유사한 측면을 가지고 있 으며(Suh, 2014), 성적 억압 또는 마조히즘(masochism) 인 형태의 표현이다. 이와 같이 남성블로그에 나타 난 본질적 자아이미지는 1차적 욕망, 실제적 현실, 대상 a, 주이상스, 성적 도착으로 나타났고, 세부속 성과 사례는 〈Table 4 〉와 같다.

\section{Conclusion}

블로그는 사용자 참여 중심의 웹 2.0 시대를 대 표하는 소셜네트워크로 블로거가 콘텐츠 생성의 주체이듯, 패션블로그에서 블로거는 이미지의 주체 가 되었다. 본 연구는 연구자가 여성블로그를 중심 으로 자아이미지를 분석한 선행연구의 확장으로 같은 분석의 틀을 적용하여, 남성블로그에 관한 사 례연구 위주로 진행되었다. 연구의 결과, 글로벌 패 션블로그에서 여성블로거와 마찬가지로 남성블로 거의 퍼스널 스타일은 기존의 패션 매체에서 제 3
자의 시각으로 연출된 패션이미지와 차별화되며, 이미지의 주체로서 블로거의 시각이 반영된 자아 이미지로서 의미를 지님을 확인하였다. 남성의 자 아이미지는 분석 틀에 따라 상상적 자아는 나르시 시즘, 퇴행, 동일시, 가상성, 사회적 자아는 역할의 상징성과 타자의 욕망, 본질적 자아는 1차적 본능, 실제적 현실, 대상 $\mathrm{a}$, 주이상스, 성적 도착의 세부 유형으로 분석되었고, 여성블로그에 나타난 자아이 미지와 유사한 결과를 도출하였다. 사례의 유형은 거의 일치하나, 여성블로거들이 좀 더 다양한 영감 을 가지고 스타일을 연출하며, 자신의 감정 표현에 있어서 좀 더 적극적인 것으로 나타났다.

첫째, 남성블로그에서도 개인의 상상적 자아를 가장 자유롭게 표현할 수 있으며, 1 차적 본능과 내 면의 현실을 표출하는 본질적 자아를 가시화 할 수 있다는 퍼스널 블로그의 가장 큰 특징이 잘 드러나 고 있다. 나르시시즘은 신체적 만족보다는 자신의 패션스타일에 대한 자신감으로 나타났고, 특히 20 
세기 패션의 재현으로 나타난 퇴행과, 영화, 음악 등 문화-예술에 대한 동일시가 두드러졌다. 가상 성은 여성블로그에서 신화적, 몽환적, 초현실적, 동 화적 등 다양한 속성으로 드러난 반면, 남성블로그 에서는 동화적, 초현실적의 몇 가지 사례로만 등장 하였다. 둘째, 타인의 욕망의 대상으로서 패션의 물 질적 속성을 대표하는 사회적 자아이미지는 남성 과 여성블로그에서 모두 동일한 수준으로 나타났 고, 블로거의 인지도에 따라 콜라보레이션 등 패션 계에서의 다양한 활동은 편차가 있었다. 남성은 역 할의 상징성에 있어서 여성에 비하여 인간관계나 개인적인 일상의 자기소개보다는 블로그 활동에 대 한 소신과 비전 등이 좀 더 주류를 이루었다. 셋째, 본질적 자아도 여성블로그와 마찬가지로 블로거의 성향에 따라 표출의 정도가 다르나, 블로거의 1 차 적 본능과 내적 갈등으로 표현되는 주이상스가 가 장 두드러졌고, 물신적 페티시즘으로 표현된 대상 $\mathrm{a}$ 도 나타났다. 성적 도착의 경우, 성적 노출과 왜곡, 억압으로 나타나는 것은 여성과 유사하나, 남성의 경우 여성의 스타킹, 하이힐, 란제리 등의 착의로 표현되는 것이 특징적이었다.

블로그는 패션계에서 남녀 성별의 구분이 사라 지며, 어느 때보다 두드러지고 있는 남성의 외모지 향적 경향을 반영하고 있는 새로운 매체로 주목되 고 있다. 블로그에 나타난 남성의 퍼스널 스타일은 이미지의 주체로서 21 세기 변화하는 남성의 자아 이미지를 표현하고 있기 때문에, 패션시스템에서 디자인과 마케팅, 홍보에 적극적으로 활용될 수 있 으며, 급성장하고 있는 남성의 패션과 뷰티마켓에 의미있는 소비자분석 자료로서 가치를 지닌다. 본 연구는 웹 2.0 이라는 매체 환경에서 남성의 자아이 미지 특성에 주목하여, 남성 패션에서 스타일 분석 의 기초자료를 마련하고자 하였다. 이를 바탕으로 남성의 자아이미지 유형에 나타난 퍼스널 스타일 을 분석하여 최근 남성의 이미지 변화와 패션에 나 타난 조형적 특성을 분석하는 후속 연구를 진행하 고자 한다.

\section{References}

Adam, G.(2011a, January 24). The sorcerers sone. iamgalla.com. Retrieved on August 20, 2014, from http://www.iamgalla.com/2011/01/sorcerers-sone. $\mathrm{html}$

Adam, G.(2011b, May 3). Heart skips a beat. iamgalla. com. Retrieved on August 20, 2014, from http:// www.iamgalla.com/2011/05/heart-skips-beat.html Adam, G.(2011c, June 16). Once upon a time. iamgalla. com. Retrieved on August 20, 2014, from http:// www.iamgalla.com/2011/06/once-upon-time.html

Adam, G.(2012, July 25). 70's groove. iamgalla.com. Retrieved on August 20, 2014, from http://www. iamgalla.com/2012/07/70s-groove.html

Adam, G.(2013a, May 9). Iamgalla is evolving. iamgalla. com. Retrieved on August 7, 2014, from http:// www.iamgalla.com/2013/05/iamgalla-is-evolving. $\mathrm{html}$

Adam, G.(2013b, December 9). Z zegna. amgalla. com. Retrieved on August 7, 2014, from http:// www.iamgalla.com/2013/12/zegna.html

Adam, G.(2014, April 9). Golden hour, sobe. iamgalla. com. Retrieved on August 20, 2014, from http:// www.iamgalla.com/2014/04/golden-hour-sobe.html

Bryan, G. Y.(2005a, March 21). Happy birthday to me. ladyboy attempt - result: failed. bryanboy.com. Retrieved on August 7, 2014, from http://www. bryanboy.com/bryanboy_le_superstar_fab/2005/03 /happy_birthday_-2.html

Bryan, G. Y.(2005b, March 22). It's holy week. Time for all the satanic souls to come out. bryanboy. com. Retrieved on August 7, 2014, from http:// www.bryanboy.com/bryanboy_le_superstar_fab/2 005/03/its_holy_week_t.html

Bryan, G. Y.(2007, October 5). Potato craving. bryanboy. com. Retrieved on August 7, 2014, from http:// www.bryanboy.com/bryanboy_le_superstar_fab/2 007/10/potato-craving.html

Bryan, G. Y.(2009, July 30). Sick and hot. bryanboy. com. Retrived on August 7, 2014, from http:// littlefashionisto.com/random/sick-and-hot/

Bryan, G. Y.(2011a, March 2). Mugler fall winter 2011 womenswear show invitation. bryanboy.com. 
Retrieved on August 7, 2014, from http://www. bryanboy.com/bryanboy_le_superstar_fab/2011/0 3/mugler-fall-winter-2011-womenswear-show-inv itation.html

Bryan, G. Y.(2011b, June 10). I'll die living just as free as my hair. bryanboy.com. Retrived on August 7, 2014, from http://www.bryanboy.com/bryanboy_ le_superstar_fab/2011/06/ill-die-living-just-as-fre e-as-my-hair.html

Bryan, G. Y.(2011c, August 31). Yes, we match! bryanboy.com. Retrived on August 7, 2014, from http://www.bryanboy.com/bryanboy_le_superstar _fab/2011/08/yes-we-match.html

Bryan, G. Y.(2011d, November 28). Pink phenomenon. bryanboy.com. Retrieved on August 20, 2014, from http://www.bryanboy.com/bryanboy_le_super star_fab/2011/11/pink-phenomenon.html

Bryan, G. Y.(2012, August 10). Le superstar. bryanboy. com. Retrived on August 7, 2014, from http:// www.bryanboy.com/bryanboy_le superstar fab/2 012/08/worn-to-death.html

Bryan, G. Y.(2013, March 30). Project runway Korea all-stars. bryanboy.com. Retrieved on August 7, 2014, from http://www.bryanboy.com/bryanboy_le superstar_fab/2013/03/project-runway-korea.html

Bryan, G. Y.(2014a, March 17). Resurrection. bryanboy. com. Retrieved on August 20, 2014, from http:// www.bryanboy.com/bryanboy_le_superstar_fab/2 014/03/resurrection-2.html

Bryan, G. Y.(2014b, April 4). Hot desert knight. bryan boy.com. Retrieved on August 7, 2014, from http:// www.bryanboy.com/bryanboy_le_superstar_fab/2 014/04/chanel-bag-dubai.html

Byun, J. Y.(2013). A semiologic analysis on masculinity expressed in the fashion and beauty images of male idols: Focused on music videos. Unpublished doctorial dissertation, Konkuk University, Seoul, Korea.

Choi, W. H.(2014, July 3). W fashion blogger: Design for Bryan boy. BNT news. Retrieved on August 20, 2014 from http://bntnews.hankyung.com/apps/ news?popup $=0 \&$ nid $=08 \& \mathrm{c} 1=08 \& \mathrm{c} 2=08 \& \mathrm{c} 3=00$ $\&$ nkey $=201407021750263 \&$ mode $=$ sub_view

Constantinos, T.(2012a, May 7). About. stylentonic. com. Retrieved on August 7, from http://stylentonic. com/about-2/

Constantinos, T.(2012b, October 29). Happy together. stylentonic.com. Retrieved on August 7, from http://stylentonic.com/2012/10/29/happy-together/

Constantinos, T.(2013, February 7). Militar(t)y effect. stylentonic.com. Retrieved on August 20, 2014, from http://stylentonic.com/2013/02/07/militartyeffect/

Constantinos, T.(2014a, March 20). Roar. stylentonic. com. Retrieved on August 20, 2014, from http:// stylentonic.com/2014/03/20/roar/

Constantinos, T.(2014b, April 28). Regualr...Not. style ntonic.com. Retrieved on August 20, 2014, from http://stylentonic.com/2014/04/28/regular-not/

Constantinos, T.(2014c, June 19). Vigorous sunset! stylentonic.com. Retrieved on from August 20, 2014, from http://stylentonic.com/2014/06/19/vigoroussunset/

Constantinos, T.(2014d, July 22). Hello Bambi. stylentonic. com. Retrieved on August 20, 2014, from http:// stylentonic.com/2014/07/22/hello-bambi/

Constantinos, T.(2014e, August 17). Naturally sweet. stylentonic.com. Retrieved on from August 20, 2014, from http://stylentonic.com/2014/08/17/ naturally-sweet/.C

Doopedia.(2014, July 11). Web 2.0. Naver.com. Retrieved on July 11, 2014, from http://terms.naver.com/entry. nhn?docId $=1257095 \&$ cid $=40942$ \& categoryId $=32$ 854

Fashion 2.0: Season of Change(2013). Fashion 2.0: Season of change. Yuli Ziv.

Homer, S. (2006). Jacques Lacan (S. Y. Kim, Trans.). Seoul: Eunhaeng Namu. (Original work published 2005)

Lee, E, J.(2006). Personal media era with web 2.0. KALI, 41, 20-25.

Lee, S. Y., \& Jung, L. S.(2010). An exploratory study 
on social network services in the context of web 2.0 period. The Korea Society of Management Information Systems, 29(4), 143-167.

Lee, U. Y., Byun, M. Y., \& Lee, I. S.(2006). A study for the characteristics of men' costume style on contemporary fashion: Focusing on metrosexual phenomena. Journal of the Korean Fashion \& Costume Design Association, 8(2), 125-133.

Lee. H. J., \& Kim, H. A.(2009). A study on the sexual images expressed in the 21th century men's fashion. Korean Living Science Association, 18(4), 891-902.

Marian, F. W.(2009). Uncovering fashion: Fashion communications across the media. NY: Fairchild Books.

Mc, K. L.(2009, June 27). Beat it, MJ tribute. littlefashionisto.com. Retrieved on August 20, 2014, from http://littlefashionisto.com/random/ beat-it-mj-tribute/BEAT IT, MJ tribute.

Mc, K. L.(2010a, February 25). I'm back. little fashionisto.com. Retrieved on August 7, 2014, from http://littlefashionisto.com/random/im-back/

Mc, K. L.(2010b, May 13). Escape from reality. littlefashionisto.com. Retrieved on August 20, 2014, from http://ittlefashionisto.com/fashion/1352/

Mc, K. L.(2011a, March 7). Dark birthday. little fashionisto.com. Retrieved on August 20, 2014, from http://littlefashionisto.com/lookbook/darkbirthday/

Mc, K. L.(2011b, November 1). Tangled. littlefashion isto.com. Retrieved on August 20, 2014, from http://ittlefashionisto.com/random/tangled/

Mc, K. L.(2011c, November 1). When you wish upon a star. littlefashionisto.com. Retrieved on August 20, 2014, from http://littlefashionisto.com/lookbook/ when-you-wish-upon-a-star/

Pelayo, D.(2009a, January 28). J'aime beaucoup le bonbon. katelovesme.com. Retrieved on August 7, from http://www.katelovesme.net/2009/01/jaime -beaucoup-le-bonbon.html

Pelayo, D.(2009b, November 1). Halloween icon: Pugsley. katelovesme.com. Retrieved on August 20, 2014, from http://www.katelovesme.net/2009/ 11/halloween-icon-pugsley.html

Pelayo, D.(2009c, November 21). Madrid gets horny (2). katelovesme.com. Retrieved on August 20, from http:/www.katelovesme.net/2009/11/madridgets-horny-2.html

Pelayo, D.(2009d, December 11). When PP met VW. katelovesme.com. Retrieved on August 20, 2014, from http://www.katelovesme.net/2009/12/when-pp-me t-vw.html

Pelayo, D.(2010, September 26). That's me, in my room by the Independent. katelovesme.com. Retrieved on August 7, from http://www.katelovesme.net/ 2010/09/thats-me-in-my-room-by-independent.html

Pelayo, D.(2012, December 17). No more guns. kate lovesme.com. Retrieved on August 7, from http:// www.katelovesme.net/2012/12/no-more-guns.html

Pelayo, D.(2014, June 13). Featured in GQ (Turkey). katelovesme.com. Retrieved on August 7, from http://www.katelovesme.net/2014/06/featured-ingq-turkey.html

Suh, S. E.(2014). The representation of ego-images and fashion styles on the personal fashion blogs. Unpublished doctorial dissertation, Seoul National University, Seoul, Korea.

World culture dictionary.(2005, August 20). Metrosexual. Naver.com. Retrieved on September 3, 2014, from http://terms.naver.com/entry.nhn?docId=1846117 $\&$ cid $=43114 \&$ categoryId $=43114$

Wright, E.(1993). Psychoanalytic criticism: Theory in practice (Y. T. Kwon, Trans.). Seoul: Munye. (Original work published 1984)

Yoon, J. Y., \& Yoo, T. S.(2011). An analysis of sexual image types of men's fashion - In TV trendy dramas. Korea Society of Design Trend, 31, 17-28. 